\title{
BITWA POD KAMIEŃCEM PODOLSKIM 22 PAŹDZIERNIKA 1633 ROKU - PRÓBA CHARAKTERYSTYKI
}

\begin{abstract}
Streszczenie. Kiedy w latach 1632-1634 Rzeczpospolita Obojga Narodów toczyła wojnę z Rosją, w tym samym czasie jeden z urzędników tureckich, sandżakbej sylistryjski Mehmed Abazy pasza dokonał najazdu na okolice Kamieńca Podolskiego. Zarówno dowódca turecki jak i polsko-litewski mieli podobne problemy organizacyjne. Z powodu wojny Rzeczpospolitej z Rosją i Imperium Osmańskiego z Persją, konflikt ten od początku rozgrywał się w cieniu większych zmagań na odległych frontach, przez co niemożliwe było wykorzystanie pełnego potencjału walczących państw, konieczna była współpraca z innymi podmiotami (dla Koniecpolskiego z magnatami kresowymi i Kozakami, dla Abazy Mehmeda z lennikami osmańskimi, niektórymi ordami tatarskimi i innymi namiestnikami prowincji tureckich), nawet komunikacja z władzą centralną była wyjątkowo niestabilna. Mimo to, dzięki lepszej organizacji, zebraniu zawczasu odpowiednich informacji o przeciwniku, odpowiednim przygotowaniu terenu, doświadczeniom wojen szwedzkich lat 1626-1629 i własnym umiejętnościom to hetman Koniecpolski mógł cieszyć się zwycięstwem w stoczonej 22 października 1633 r. bitwie pod Kamieńcem Podolskim.
\end{abstract}

Słowa kluczowe: Stanisław Koniecpolski, Władysław IV Waza, Kamieniec Podolski 1633, Tatarzy, Chanat Krymski, Abazy Mehmed pasza, Murad IV, Orda Nogajska, Kantymir mirza, wojna polsko-turecka 1633-1634, najazd Abazy paszy, Mołdawia, Wołoszczyzna, Rzeczpospolita Obojga Narodów, Polska, Litwa, Wojna polsko-rosyjska 1632-1634, epoka nowożytna, historia wojskowa, Imperium Osmańskie, Turcja.

\section{Przyczyny i okoliczności bitwy kamienieckiej. Najazd Abazy paszy}

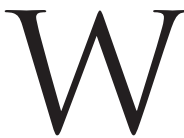
alki pod Kamieńcem Podolskim nie wydają się być wyczerpująco opracowane ${ }^{1}$. W dużej mierze ma na to wpływ małe znaczenie całego konfliktu znanego w historiografii jako najazd Abazy

${ }^{1}$ Najważniejsze polskojęzyczne opracowania i źródła dotyczące wojny polsko-tureckiej, zwanej najazdem Abazy paszy to: Korespondencja Stanisława Koniecpolskiego, hetmana wielkiego 
paszy i fakt, że rozgrywały się one równolegle do toczonych ze znacznie większym rozmachem starć pod Smoleńskiem przeciw Moskwie. Niniejsze opracowanie ma na celu przybliżenie tej bitwy oraz stanowi próbę rekonstrukcji przebiegu zdarzeń.

Po wojnie polsko-tureckiej w latach 1620-1621, zwanej chocimską, następny duży konflikt polsko-turecki wydawał się bardzo odległy. Imperium Osmańskie znajdowało się w stanie całkowitej zapaści po kilku przewrotach pałacowych. Kiedy w 1623 r. władzę w Stambule przejął młody Murad IV, jego pierwszym wyzwaniem było uspokojenie państwa, stłumienie buntów przeciw jego władzy oraz odepchnięcie zagrażających od wschodu Persów. sułtanowi udało się wkrótce uporządkować sytuację wewnętrzną, spacyfikować rebeliantów, odnieść sukcesy w walkach z Persami, odtworzyć instytucje państwowe i wojskowe oraz przywrócić wpływy z podatków. Tym samym około 1630 r. Imperium Osmańskie po okresie kryzysu mogło wrócić na drogę ekspansji².

Tymczasem w Rzeczypospolitej 30 kwietnia 1632 r. zmarł król Zygmunt III Waza. Niekorzystną sytuację podczas bezkrólewia skomplikował wybuch wojny z Moskwą, której wojska przekroczyły granicę z Litwą dokładnie pięć miesięcy później, 30 września 1632 r. najeźdźcy szybko posuwali się naprzód, zajmując szereg pogranicznych zamków i oblegając Smoleńsk. Rosjanie wysłali poselstwa na dwór osmański, by zachęcić Turcję do wojny i ułatwić sobie ponowny podbój ziem utraconych podczas wielkiej smuty ${ }^{3}$. Porta ze względu na niedawne niepokoje nie chciała otwarcie wypowiadać wojny na odległym froncie, ale częste rajdy kozackie na miasta czarnomorskie wpłynęły na zmianę tego stanowiska ${ }^{4}$. Co więcej, na terenach Zaporoża

koronnego 1632-1636, wyd. A. Biedrzycka, Kraków 2005; Katalog rękopisów orientalnych ze zbiorów polskich, t. 1, cz. 1: Katalog dokumentów tureckich. Dokumenty do dziejów Polski i krajów ościennych w latach 1455-1672, wyd. Z. Abrahamowicz, red. A. Zajączkowski, Warszawa 1959; W. Czapliński, Władysław IV i jego czasy, Wrocław 1974, s. 166-172; J. Pajewski, Buńczuk i koncerz, Warszawa 1960, s. 116-121; L. Podhorodecki, Wojna polsko-turecka 1633-1634, „Studia i Materiały do Historii Wojskowości” 1976, t. 20, s. 27-72.

${ }^{2}$ S. Shaw, Historia Imperium Osmańskiego i Republiki Tureckiej, t. 1, 1280-1808, tłum. B. Świetlik, Warszawa 2012, s. 301-310.

${ }^{3}$ M.A. Pieńkowski, „Jak Osmanowa potęgę żelazem zniósł”. Najazd Abazy paszy i bitwa pod Kamieńcem Podolskim (Paniowcami), https://histmag.org/Jak-Osmanowa-potege-zelazem-zniosl--Najazd-Abazy-paszy-i-bitwa-pod-Kamiencem-Podolskim-Paniowcami-8588, dostęp: 10.07.2017.

${ }^{4}$ Wyprawy kozackie na tureckie porty czarnomorskie były często poruszanym problemem w relacjach polsko- osmańskich. Abazy pasza pisał do hetmana Stanisława Koniecpolskiego: „Kozacy jednak wasi na morze wyszedłszy państwa Cesarza J.M. wojują, ludzi ubogich w niewolą biorą, okręty palą, kupców wniwecz obracają", Abazy pasza do Stanisława Koniecpolskiego [przed 16 IX 1633], [w:] Korespondencja..., s. 141. Co bardziej zuchwałe wyprawy opisywano 
zaczęły powstawać nowe umocnione obozy kozackie, zwane pałankami, mające służyć do uszczelnienia granicy polsko-tatarskiej, ale w praktyce wykorzystywane jako bazy wypadowe na tereny podległe sułtanowi. W maju 1632 r. odwołano ze stanowiska sandżak beja sylistryjskiego Murtazy paszę, przyjaznego wobec Polski ze względu na dobre relacje z hetmanem wielkim koronnym Stanisławem Koniecpolskim, a na jego miejsce powołano Mehmeda Abazy, zdegradowanego z poprzedniego urzędu jakim był bejlerbej Bośni ${ }^{5}$. Ten zaś, postanowił powiększyć wpływy tureckie i umocnić własną pozycję, wywołując wojnę z osłabioną konfliktem smoleńskim Rzeczpospolitą. Wydaje się, że również i sułtan nie był przeciwny podjęciu tych działań, chcąc zapewne sprawdzić możliwość powodzenia ewentualnej walnej wyprawy na państwo polsko-litewskie w przyszłości. Tym bardziej, że działania wojenne z Persją zostały wstrzymane i wiele wskazywało na to, że zostaną zakończone, co pozwoliło na zebranie sił i poszukiwanie ewentualnych kierunków ekspansji w niedalekiej przyszłości ${ }^{6}$. Wkrótce, Mehmed Abazy rozpoczął przygotowania do najazdu pod pretekstem poskromienia najazdów kozackich i zniesienia służących im umocnień7.

w kronikach tureckich, vide: Zatargi z Ottomanami z powodu Kozaków i dziennik woyny chocimskiey z roczników Naima Efendi, [w:] Collectanea z dziejopisów tureckich rzeczy do historyi polskiey służących. Z dodatkiem objaśnień potrzebnych i krytycznych uwag, wyd. J. Sękowski, t. 1, Warszawa 1824, s. 109.

${ }^{5}$ Z listów wymienianych między Murtazą a Koniecpolskim można zauważyć, że byli sobie życzliwi. Sam pasza, kiedy został wezwany do Porty w związku ze zmianą stanowiska, prosił hetmana o napisanie listów poświadczających jego dobre zarządzanie pograniczem, dla wezyra, Korespondencja..., s. 100-101.

${ }^{6}$ O wstrzymaniu działań wojennych z Persją przed konfliktem polsko-tureckim: W. Czermak, Plany wojny tureckiej Władysława IV, Kraków 1895, s. 26.

${ }^{7}$ Warto zwrócić uwagę, że chociaż w korespondencji dyplomatycznej dotyczącej przyczyn wojny, dominuje żądanie zniesienia pałanek kozackich, to w kronice Naima efendiego powód jest opisany zupełnie inaczej: „w pierwszych dniach księżyca Ramazan roku 1043 (około środka lutego 1633), przybył w poselstwie do Carogrodu jeden ze znamienitszych Lehów, który, jak powiadano, był wezyrem ich króla. Abazy pasza, bejlerbej uzyjski, miał poruczone sobie układy o zawarcie przymierza z tym narodem. Lehowie żądali utrzymać pokój na warunkach umówionych za czasów Sulejmana cesarza, lecz ten znamienity władca, tak z powodu przyjaźni z Syndżyzmendem (Zygmuntem), jak przez wzgląd na usługi przezeń okazane, na lekką bardzo zezwolił był daninę; gdy przeciwnie podług traktatu zawartego z cesarzem Osmanem w czasie chocimskiej wyprawy król przyjął obowiązek płacenia corocznie znakomitego haraczu. Przeto Abaze pasza, odmówiwszy zawarcie przymierza urzędnikom królewskim, jedno pod warunkiem płacenia żołdu, jaki pod Chocimiem był uzgodniony, przełożył Dywanowi, że nie inaczej traktować o pokój z Lehami należy, jak po wypełnieniu przez nich tego artykułu, że zaległy od lat dziesięciu haracz wynosi tak okrągłą sumę, jakiej skarb muzułmański pozbawiać żadną nie wypada miarą. Skoro list tego urzędnika złożony Padyszachowi oświecił go prawdziwego stanu naszych z Lehami stosunków", cyt. za: Zatargi z Ottomanami..., s. 191. 


\section{Siły i dowódcy obu stron}

W Rzeczpospolitej zdawano sobie sprawę z zagrożenia tureckiego, tym bardziej, że informatorzy Koniecpolskiego donosili mu o przygotowaniach nowego beja. Ze względu na agresję moskiewską państwo polsko-litewskie nie było w stanie wystawić większych sił do walki przeciw nowemu agresorowi i ciężar obrony państwa spadł w znacznej mierze na barki magnatów i Kozaków - w składzie zebranej przez hetmana armii na 11000 żołnierzy tylko 4000 było utrzymywanych z kasy państwowej. Mimo to, można było polegać na pocztach prywatnych, których doświadczenie było porównywalne z jednostkami kwarcianymi, zaś ich właściciele zdawali sobie sprawę, że skuteczna obrona tych terenów to również obrona ich majątków i poddanych.

\section{Tabela 1}

Skład armii koronnej pod Kamieńcem w 1632 r.

\begin{tabular}{|c|c|c|c|c|c|}
\hline \multicolumn{3}{|c|}{ Jednostki kwarciane } & \multicolumn{3}{|c|}{ Jednostki prywatne } \\
\hline Formacja & Jednostka & $\begin{array}{c}\text { Liczeb- } \\
\text { ność }\end{array}$ & Formacja & Jednostka & $\begin{array}{c}\text { Liczeb- } \\
\text { ność }\end{array}$ \\
\hline \multirow[t]{7}{*}{$\begin{array}{l}\text { Husaria } \\
\text { (7 chorągwi) }\end{array}$} & $\begin{array}{l}\text { Chorągiew } \\
\text { hetmańska }\end{array}$ & 210 & b. d. & $\begin{array}{l}\text { Janusza Wiśnio- } \\
\text { wieckiego }\end{array}$ & 1500 \\
\hline & $\begin{array}{l}\text { Tomasza Zamoy- } \\
\text { skiego }\end{array}$ & 100 & & $\begin{array}{l}\text { Stanisława Lubo- } \\
\text { mirskiego }\end{array}$ & 2000 \\
\hline & $\begin{array}{l}\text { Stanisława Re- } \\
\text { wery Potockiego }\end{array}$ & 100 & & $\begin{array}{l}\text { Tomasza Zamoy- } \\
\text { skiego }\end{array}$ & 1000 \\
\hline & $\begin{array}{l}\text { Mikołaja Potoc- } \\
\text { kiego }\end{array}$ & 100 & & $\begin{array}{l}\text { Janusza Tyszkie- } \\
\text { wicza }\end{array}$ & 500 \\
\hline & $\begin{array}{l}\text { Łukasza Żółkiew- } \\
\text { skiego }\end{array}$ & 100 & & $\begin{array}{l}\text { Jerzego Zasław- } \\
\text { skiego }\end{array}$ & 1000 \\
\hline & $\begin{array}{l}\text { Stanisława Dani- } \\
\text { łowicza }\end{array}$ & 100 & & $\begin{array}{l}\text { Hieronima } \\
\text { Sieniawskiego }\end{array}$ & 300 \\
\hline & $\begin{array}{l}\text { Władysława } \\
\text { Myszkowskiego }\end{array}$ & 100 & & Chojskiego & 150 \\
\hline \multirow[t]{4}{*}{$\begin{array}{l}\text { Jazda kozacka } \\
\text { (14 chorągwi) }\end{array}$} & $\begin{array}{l}\text { Łukasza Żółkiew- } \\
\text { skiego }\end{array}$ & 150 & & Niemierzyca & 150 \\
\hline & $\begin{array}{l}\text { Jana Odrzywol- } \\
\text { skiego }\end{array}$ & 150 & & Sieniuta & 150 \\
\hline & Żółtowskiego & 150 & $\begin{array}{l}\text { Piechota } \\
\text { i wsparcie }\end{array}$ & $\begin{array}{l}\text { Kozacy } \\
\text { zaporoscy }\end{array}$ & 1250 \\
\hline & Skalskiego & 100 & & $\begin{array}{l}\text { Mieszczanie, } \\
\text { chłopi i szlachta }\end{array}$ & Kilkaset \\
\hline
\end{tabular}




\begin{tabular}{|c|c|c|c|c|c|}
\hline \multicolumn{3}{|c|}{ Jednostki kwarciane } & \multicolumn{3}{|c|}{ Jednostki prywatne } \\
\hline \multirow[t]{2}{*}{ Formacja } & Jednostka & $\begin{array}{l}\text { Liczeb- } \\
\text { ność }\end{array}$ & Formacja & Jednostka & $\begin{array}{c}\text { Liczeb- } \\
\text { ność }\end{array}$ \\
\hline & Samuela Łaszcza & 100 & Artyleria & $\begin{array}{l}\text { Działa wojsk } \\
\text { kwarcianych, } \\
\text { miejskie, prywat- } \\
\text { ne i kozackie }\end{array}$ & $\begin{array}{l}\text { Kilka- } \\
\text { dziesiąt } \\
\text { dział } \\
\text { (ok. 40) }\end{array}$ \\
\hline \multirow[t]{9}{*}{ Jazda kozacka } & $\begin{array}{l}\text { Wawrzyńca } \\
\text { Jeżowskiego }\end{array}$ & 100 & & & \\
\hline & $\begin{array}{l}\text { Aleksandra } \\
\text { Cetnera }\end{array}$ & 100 & & & \\
\hline & $\begin{array}{l}\text { Mikołaja Cze- } \\
\text { twertyńskiego }\end{array}$ & 100 & & & \\
\hline & $\begin{array}{l}\text { Jerzego Kruszyń- } \\
\text { skiego }\end{array}$ & 100 & & & \\
\hline & $\begin{array}{l}\text { Mikołaja Potoc- } \\
\text { kiego }\end{array}$ & 100 & & & \\
\hline & $\begin{array}{l}\text { Adriana Choci- } \\
\text { mirskiego }\end{array}$ & 100 & & & \\
\hline & $\begin{array}{l}\text { Aleksandra Ba- } \\
\text { łabana }\end{array}$ & 100 & & & \\
\hline & Potockiego & 100 & & & \\
\hline & Mikołaja Jordana & 100 & & & \\
\hline \multirow{3}{*}{$\begin{array}{l}\text { Dragoni } \\
\text { ( } 1 \text { regiment } \\
\text { i } 2 \text { kompanie) }\end{array}$} & Kaspra Denhoffa & 400 & & & \\
\hline & Jana Meriana & 150 & & & \\
\hline & Landkrotada & 100 & \multicolumn{3}{|c|}{$\begin{array}{l}\text { Razem: ponad } 11000 \text { żołnierzy i kilkadzie- } \\
\text { siąt tysięcy sług obozowych }\end{array}$} \\
\hline
\end{tabular}

Źr ódło: L. Podhorodecki, Wojna polsko-turecka..., s. 44-46.

Oprócz doświadczonych żołnierzy, obrońcy mogli się również poszczycić znakomitym dowódcą. Stanisław Koniecpolski uznawany był za jednego z lepszych wodzów ówczesnej Rzeczpospolitej. Doświadczenia wojenne wyniesione z walk z Moskwą, Kozakami, Tatarami, Turkami i Szwedami oraz jego dotychczasowa lojalność wobec Wazów stanowiły wystarczający powód, by właśnie on został wyznaczony do obrony kraju pod nieobecność króla prowadzącego kampanię smoleńską. Urodzony ok. 1591 r. został hetmanem polnym koronnym już w 1618 r., nie mając jeszcze 30 lat. Był uczniem hetmana Stanisława Żółkiewskiego. Choć jego pierwsze walki 
z Turkami zakończyły się klęską pod Cecorą w 1620 r. i niewolą, wykorzystał ten czas do poznania przeciwnika i nawiązania kontaktów z osmańskimi urzędnikami, od których otrzymywał potem informacje o sytuacji na dworze sułtana. Duży wpływ na rozwój jego umiejętności dowódczych miała wojna o ujście Wisły (1626-1629). Musiał wówczas dostosować staropolską sztukę wojenną do innowacji wprowadzonych przez króla szwedzkiego Gustawa II Adolfa. Pewne rozwiązania podpatrzone wówczas u przeciwników zostały potem skutecznie zaadoptowane podczas konfliktu z Abazy paszą. Jego sposób prowadzenia działań charakteryzował się, w przeciwieństwie do innych wodzów tego pokolenia, dużą ostrożnością, starannym rozpoznaniem sił przeciwnika, uwzględnieniem roli terenu i kordonowym rozstawianiu swoich oddziałów, a rzadziej śmiałymi manewrami taktycznymi. Wydawałoby się, że te cechy nie były odpowiednie dla walk na Dzikich Polach, szczególnie przeciw lotnym zagonom tatarskim, ale Koniecpolski dość dobrze sprawdzał się w roli obrońcy południowych granic. W dużej mierze jego skuteczność polegała też na umiejętnym doborze ludzi, jak np. Stefan Chmielecki, czy Samuel Łaszcz, których inicjatywa i szybkość znakomicie uzupełniały system dowodzenia ich przełożonego ${ }^{8}$.

Po stronie tureckiej również nie można było wykorzystać pełnego potencjału mobilizacyjnego. Niedawne zarazy i skupienie większości sił na perskim froncie sprawiała, że Abazy pasza musiał polegać na współpracy z innymi sandżakbejami, którzy byli równi mu statusem oraz na lennikach tureckich: Mołdawii, Wołoszczyźnie i tatarach budziackich. Były to wojska o różnym poziomie sprawności, jednak zazwyczaj ich morale było bardzo niskie, bowiem po niedawnym kryzysie byli źle wyekwipowani i opłacani. Mobilizacja była tym trudniejsza, że zarówno lennicy, jak i możni tureccy nie chcieli angażować się w trudny konflikt na północnych rubieżach imperium. Mimo to udało się zebrać znaczące, liczące ponad 24000 żołnierzy, siły, dwukrotnie przewyższające swą liczbą wojska obrońców. Najwartościowsze z pewnością były czambuły tatarskie, dobrze znające teren walk i przeciwnika, lecz z powodu toczącej się wówczas wojny domowej na Krymie, ich liczba nie była zbyt wielka. Poniższa tabela przedstawiająca szacunkową liczebność oddziałów tureckich oparta jest na źródle Regestr wojska tureckiego przy tym, co u pana Żółkiewskiego, starosty kałuskiego, pojmany cytowanym w artykule Leszka Podhorodeckiego pt. Wojna polsko-turecka...

${ }^{8}$ Szerzej o Koniecpolskim: L. Podhorodecki, Hetman Stanisław Koniecpolski, Warszawa 2011, passim. O życiu Stefana Chmieleckiego i jego dokonaniach: W. Dobrowolska: Chmielecki Stefan, [w:] Polski Słownik Biograficzny, t. 3, Kraków 1937, s. 318-320. 
Tabela 2

Liczebność armii osmańskiej pod Kamieńcem w 1632 r.

\begin{tabular}{|c|c|c|}
\hline Jednostka & Liczebność & Uwagi \\
\hline Nadworna Abazy Paszy & 800 & Zapewne głównie kawaleria \\
\hline Beja Widynia & 1000 & Głównie kawaleria \\
\hline Paszy czermeńskiego & 600 & \\
\hline Beja Wizy & 700 & \\
\hline Akindżi & 500 & Nieregularne oddziały kawalerii \\
\hline Madzia Utom & 600 & \\
\hline Szabakana & 400 & \\
\hline Brata Szabakana & 200 & \\
\hline Szachmet bej & 300 & \\
\hline Spahisi Balinka & 800 & Kawaleria \\
\hline Piechota & 2500 & Zapewne nieregularne oddziały \\
\hline Ochotnicy z Dobrudży & 600 & \\
\hline Janczarzy & 600 & Regularna piechota \\
\hline Semeni & 200 & Nieregularna piechota \\
\hline \multicolumn{3}{|c|}{ Jednostki lenników Turcji } \\
\hline $\begin{array}{l}\text { Tatarzy budziaccy } \\
\text { Orak mirzy Husseina } \\
\text { i synów Kantymira }\end{array}$ & 15000 & $\begin{array}{l}\text { Najprawdopodobniej to błędne sza- } \\
\text { cunki, zważywszy na potencjał skłó- } \\
\text { conego Chanatu, nie mogło być wię- } \\
\text { cej niż } 5000 \text { jeźdźców }{ }^{\mathrm{a}}\end{array}$ \\
\hline $\begin{array}{l}\text { Mołdawianie Mojżesza } \\
\text { Mohyły }\end{array}$ & 4300 & Zapewne głównie piechota \\
\hline
\end{tabular}

a Według najbardziej wiarygodnych ustaleń Chanat Krymski ze względu na gęstość zaludnienia nie był nigdy w stanie wystawić więcej niż 30000 wojowników, dla Tatarów dużymi wyprawami były już takie, które angażowały ok. 5000 jeźdźców. Ze względu na ówczesną sytuację podziału wśród ordyńców i częstych wojen domowych taka liczba wydaje się też być maksymalnym wysiłkiem dużo mniejszej ordy budziackiej w omawianym czasie, L. Podhorodecki, Wojna..., s. 43; 0. Górka, Liczebność Tatarów krymskich i ich wojsk, „Przegląd Historyczno-Wojskowy" 1936, t. 8, nr 2, s. 185-295. 
Tabela 2 cd.

\begin{tabular}{|l|c|l|}
\hline \multicolumn{1}{|c|}{ Jednostka } & Liczebność & Uwagi \\
\hline $\begin{array}{l}\text { Wołosi Mateusza } \\
\text { Besaraba }\end{array}$ & 5700 & Zapewne głównie piechota \\
\hline Artyleria & 30 dział & \\
\hline $\begin{array}{l}\text { Razem: ok. 34 } 600 \text { (po zweryfikowaniu liczebności Tatarów - 24 600) ludzi, w tym ponad } \\
4000 \text { piechoty. }\end{array}$ \\
\hline
\end{tabular}

Źr ó dło: L. Podhorodecki, Wojna polsko-turecka..., s. 43.

Stojący na ich czele Mehmed Abazy pasza, uważany był za dobrego wodza. Pochodził najprawdopodobniej z Kaukazu, z grupy etnicznej Abchazów. Był niewolnikiem osmańskim, który zrobił zawrotną karierę, co było pewną normą wśród urzędników sułtanów. Jako protegowany Halila paszy, osiągał kolejne stanowiska: miecznika tegoż paszy, następnie admirała, gubernatora prowincjonalnego (sandżakbeja) w Maras, aż w końcu został gubernatorem generalnym (bejlerbejem) prowincji Erzurum w dzisiejszej północno-wschodniej części Turcji, zatem niedaleko od swoich rodzinnych stron. Był lojalny wobec sułtana Osmana II, pod którego dowództwem brał udział w wojnie chocimskiej w 1621 r., co ciekawe, wówczas, tak jak w trakcie wyprawy na Polskę, dowodził siłami Wołochów, Mołdawian i Tatarów. Po śmierci władcy zamordowanego przez janczarów podczas przewrotu pałacowego w 1622 r., stanął na czele powstania Celalich. Jego sukcesy jako wodza sprawiły, że w niedługim czasie buntownicy zagrozili Konstantynopolowi i wkrótce w wyniku kolejnego spisku pałacowego obalono sułtana Mustafę I na rzecz Murada IV. Chociaż Abazy kontynuował walkę przeciw wojskom rządowym jeszcze za panowania nowego sułtana - nawet w trakcie wojny z Persją. Mimo to, nowy władca, postąpił z buntownikiem niezwykle łagodnie. Nie tylko darował mu życie po klęsce pod Kayseri w 1628 r., ale nawet mianował na wpływowe stanowisko bejlerbeja Bośni. Zapewne duży wpływ na nominację miał też talent dowódczy Abazy. Dodatkowo monarcha miał pewność, że umieszczony w obcym środowisku, pozbawiony kontaktów awanturnik przez dłuższy czas nie będzie w stanie prowadzić działań zagrażających jego władzy. Tym niemniej wiele wskazuje na to, że nie miał pełnego zaufania do Abchaza, skoro szybko przeniósł go na niższe w hierarchii stanowisko sandżakbeja Sylistrii, podległe formalnie bejlerbejowi Rumelii9.

${ }^{9}$ Strona polska, w tym sam Koniecpolski, sądzili, że Abazy jest zbiegłym Rusinem o imieniu Iwaszko, ale nie należy traktować poważnie tych domysłów. 0 postaci Abazy Mehmeda 


\section{Bitwa pod Kamieńcem Podolskim}

Koniecpolski już 8 października ściągał swoje oddziały do Kamieńca. Tymczasem dopiero 16 października Turcy dotarli do Chocimia. W ciągu 2 tygodni pokonali zaledwie $200 \mathrm{~km}$, poruszali się zatem tak wolno, że hetman zaczął powątpiewać w możliwość ataku. Do tego czasu umocnienia polskie były już ukończone i zdatne do obrony ${ }^{10}$. Jak opisywał w swoim diariuszu naoczny świadek, Mikołaj Ostroróg:

Mieliśmy w tyle Kamieniec i obóz nasz okopany, z boku prawego mieliśmy bardzo głęboki i szeroki skalisty rów, którym rzeka Smotrycz idzie. Na lewym boku, choć ku górze nie bardzo dobry miał nieprzyjaciel przystęp, jednak J.M.P. Hetman trzy szańce w tamtą stronę usypać kazał i dwa taborki dla piechoty postawił. Co wszystko armatą i piechotą dobrze osadziwszy między tymi szańcami i taborkami kilkanaście chorągwi postawił per traversam alteram frontem exercitus tam uczyniwszy skąd się nieprzyjaciela zarownie spodziewał, jako i tu z czoła, ale nie mniej i czoło dobrze obwarował, bo także między dwiema redutami go postawił, które utramque vallem, między którym wojsko stało dobrze strychowali i żeby nas nieprzyjaciel i ogarnąć nie mógł i nolentes ku stoczeniu bitwy przymusić, na całe prawie skrzydło Xiążę JMść Wiśniowieckie, lewe Pan Starosta Kamieniecki trzymali w posiłku Pułk Hetmański z P. Starostą Kałuskim i z Panem Wojewodą Kijowskim stały, claude bat agmen Pan Wojewoda bracławski z Panem Margrabiem i inszymi kilką chorągwiami kozackimi, tak duplicem frontem, bo się ze dwóch stron nieprzyjaciela spodziewaliśmy, uszykowawszy czekaliśmy go z ochotą. A ponieważ na dwoje albo na troje strzelania z łuku był wzgórek, z którego nieprzyjaciel mógł z dział szkodzić nas prudenter to J.M.P. Hetman upatrzywszy postawił tam szaniec potężny i obsadził go mianowanymi Dragonami i swoja piechotą i J.M.Pana Wojewody Ruskiego z Połonnego, nad którymi Rotmistrz, P. Żarnowiecki, pewnie rycerski człowiek ${ }^{11}$.

Pierwsze oddziały tureckie pojawiły się w okolicy Kamieńca Podolskiego w środę, 19 października, ale dopiero następnego dnia straż przednia złożona z Tatarów budziackich sforsowała Dniestr. Zaraz też rozpoczęto harce, by rozpoznać stan polskiej obrony. Kilka tysięcy Tatarów od rana do późnego popołudnia grasowało wokół obozu, ale zaraz potem powrócili oni do głównych sił tureckich stojących w Chocimiu. Zapewne Abazy stwierdził, że

paszy: K. Barkey, Bandits and Bureaucrats: The Ottoman Route to State Centralization, Ithaka 1994, s. 222-223; J. Pajewski, op. cit., s. 117; L. Podhorodecki, Wojna ..., s. 31-32.

10 Ibidem, s. 46-47.

11 Diariusz z obozu spod Kamieńca opisany przez J.M. Pana Mikołaja Hrabię na Ostrorogu, Podstolego Koronnego, Rohatyńskiego, Drohowiskiego, Lisiańskiego, etc. Starostę dnia 27 października 1633 roku, [w:] Pamiętniki o Koniecpolskich. Przyczynek do dziejów polskich XVII wieku, wyd. S. Przyłęcki, Lwów 1842, s. 271-272. 
wróg jest dobrze przygotowany, bo tego samego dnia wysłał w charakterze parlamentariuszy stolnika wołoskiego i logofeta mołdawskiego. Nie był to najlepszy wybór, bo posłowie przy okazji nawiązali kontakty w interesie swych hospodarów, którzy nie chcieli zwycięstwa Imperium Osmańskiego, które mogło by wówczas zlikwidować resztki niezależności ich państewek. Z drugiej strony urzędnicy państw multańskich posiadali najlepsze kwalifikacje na posłów. Mogli bez problemu przekazać wiadomość Koniecpolskiemu bowiem na dworach Mołdawii i Wołoszczyzny język polski był jednym z języków dyplomacji, na równi z tureckim i łaciną. Hetman przyjął bardzo przyjaźnie wysłanników, zatrzymując ich aż do następnego dnia (20 października), a 21 października wysłał swoich posłów, lecz nie do nieprzyjacielskiego wodza, tylko do hospodarów. Przekazali oni, że Koniecpolski rozumie trudną sytuację lenników osmańskich, winą za konflikt obarcza tylko Abazy paszę, sam nigdy nie miał zamiaru im szkodzić. co więcej, zaproponował by pośredniczyli między nim a paszą w celu ustanowienia pokoju na dotychczasowych warunkach. Przy okazji posłowie mieli też dowiedzieć się jak najwięcej o siłach wroga. Hospodarowie, zgodnie z oczekiwaniami hetmana przyjęli gościnnie posłów, przekazali im też niektóre ważne informacje dotyczące stosunków między oficerami i dostojnikami a głównodowodzącym armii tureckiej. Pośrednictwa się nie podjęli, a na pewno nie było ono skuteczne. Już wieczorem tego samego dnia ponownie Tatarzy zaczęli nękać polskie stanowiska, zostali jednak odparci przez chorągwie kozackie, które wzięły pierwszych jeńców. Posłowie wrócili 22 października z wieściami od lenników, ale też i odpowiedzią samego Abazy paszy, który przedstawił swoje warunki pokojowe dotyczące zniszczenia kozackich pałanek (umocnionych osad skąd robiono wypady na ziemie sułtana), wysłania wielkiego posła do sułtana, podarków dla dworu osmańskiego a nawet hospodarów i zapłacenia wysokiej kontrybucji tureckiemu wodzowi oraz przyjęcia religii islamskiej, które uznano za nie do przyjęcia przez stronę polską. W czasie, gdy polscy wysłannicy zdawali relację, wódz turecki nakazał przeprawę przez Dniestr i atak na polskie pozycje. Co warto zaznaczyć i w tym wypadku armia poruszała się wyjątkowo ociężale. Pierwsze jednostki, które ukazały się obrońcom musiały czekać 5 godzin na wyrównanie szyku i dołączenie ostatnich oddziałów i armia turecka uszykowała się przed pozycjami obrońców dopiero koło południa. Także i w tym wypadku nie udało się osiągnąć zaskoczenia, na które zapewne liczył namiestnik ${ }^{12}$.

Rozstawienie sił tureckich było następujące: na prawym skrzydle stanęła kawaleria turecka pod dowództwem beja Widynia oraz ukryci w dolinie Muszy Tatarzy; w centrum główne siły Abazy paszy, wraz z jego osobistym

12 L. Podhorodecki, Wojna..., s. 49. 
pułkiem; lewe skrzydło zajęły oddziały lenników i janczarzy. Widać przy tym, że wódz turecki nie ufał Mołdawianom ani Wołochom, bowiem zaraz za ich oddziałami ustawił lojalniejsze formacje janczarów.

Po stronie polskiej rozmieszczono oddziały w następującym porządku: obóz będący na tyłach głównych sił obsadzono prywatną piechotą Tomasza Zamoyskiego i Jerzego Zasławskiego; szańce prawego skrzydła - naprzeciw Mołdawian, Wołochów i janczarów - obsadzili Kozacy i pułk Janusza Wiśniowieckiego z kawalerią, piechotą i działami, za nimi ustawiono pułk Janusza Tyszkiewicza, zaś trzeci rzut stanowił pułk Łukasza Żółkiewskiego; centrum bronił pułk Mikołaja Potockiego, za nim stał pułk hetmański pod wodzą samego Koniecpolskiego. Trzecią linią dowodził Stanisław Lubomirski; lewe skrzydło obsadził Stanisław Rewera Potocki, za nim pułki jazdy Jana Odrzywolskiego i Władysława Myszkowskiego. Przed pozycjami polskimi obsadzono piechotą trzy gwiaździste reduty, zaś najbardziej wysunięty ku przeciwnikowi fort 150 dragonami Jana Meriana i piechotą Lubomirskiego, znajdujący się między centrum a lewą flanką. Prawe skrzydło nie musiało się obawiać silnego ataku ze względu na urwisty i wysoki brzeg Smotryczy, zaś dla wsparcia lewego poza wspomnianym fortem ustawiono - sformowano jeszcze 2 linie taborów ustawionych między fortem a obozem zamykających szczelnie obronę. Szyk był bardzo głęboki w porównaniu do szerokości frontu (1 x 1,5 km), co przypomina mniejszą wersję ustawienia Chodkiewicza pod Chocimiem w 1621 r. i świadczy o typowo obronnym charakterze ${ }^{13}$. Nasycenie lewego skrzydła kawalerią, osłanianą przez ruchome wozy taborowe, świadczy o tym, że z tego miejsca miały być dokonywane wypady na pozycje wroga, a nawet oskrzydlenie jego sił, podczas jego ataku na umocnione centrum.

Warto zauważyć, że wódz turecki wpadł w pułapkę Koniecpolskiego, bo pierwszy atak zwrócił na fort, który mógł korzystać ze wsparcia ogniowego wspomnianych redut, zatem był znakomicie przygotowany do odparcia szturmów. Piasecki ocenił:

Dnia 22 października w sobotę Abazy basza pokazał się uszykowanemu przed swym obozem wojsku i wnet przywitany został rzęsistym ogniem dział ukrytych w pobliżu między rowami i udarniowanymi kopcami. Dla zniesienia tej działobitni i przebicia się do wojska polskiego ruszył najpotężniejszy swój hufiec, z którego [...] 500 ludzi utracił [...] ${ }^{14}$.

13 Ibidem, s. 49-50.

${ }^{14}$ Kronika Pawła Piaseckiego, biskupa przemyślskiego. Polski przekład wedle dawnego rękopismu, poprzedzony studyjum krytycznem nad życiem i pismami autora, wyd. A. Chrząszczewski, Kraków 1870, s. 394. 
Koniecpolski zaś raportował królowi o tych wydarzeniach:

Nastąpił tedy nieprzyjaciel ze wszystkiemi wojski swemi i widząc ten fort sobie do czynienia na przeszkodzie, a nam bardzo pomocny, tentował go tak piechotą swoją i działami, jako i jazdą, która z rezoluycją do samej palisady następowała po kilka razy chcąc go znosić, ale za każdą razą z wielką szkodą i hańbą swoją odchodzić musieli. Potym, iż wszystko wojsko, zostawiwszy go część na zawadzie dla posiłku, bez wszelkiego szyku w harc był puścił, nie było sposobu na rozsypanego po polu harcownika chorągwie rozpuszczać, przychodziło tylko strzelbą nieprzyjaciela psować ${ }^{15}$.

Widać więc, że atak na fort zakończył się całkowitym niepowodzeniem, mimo, że jak pisał polski dowódca, wskutek działań harcowników ta umocniona pozycja była on izolowana od ewentualnej odsieczy głównych sił koronnych. Abazy pasza, po porażce w centrum postanowił zaatakować ze swojego lewego skrzydła szańce kozackie:

dawszy pokój szańcom, uderzył na skrzydło Xcia Wiśniowieckiego, gdzie go też rażono bardzo dobrze i z tamtego pierwszego szańcu z boku i z drugiego co był przy skrzydle Xięcia Jego Mści z czoła, do tego, że Xiążę Kozaków Zaporoskich i piechotę swoją zemknął skałą przecz w bok nieprzyjacielowi, skąd go mocno szkodzono ${ }^{16}$.

Multańczykowie zaś z Wołoszą, których uchylających się od walki groźnymi bułatów zamachami napędzali do boju Turcy, [ci zaś - przyp. AB], nie chcąc za sprawę pohańców bić się z chrześcijanami, zaledwie rozpocząwszy utarczkę, tył zaraz podali ${ }^{17}$.

Sam Koniecpolski nie wspomina o ataku na swoje prawe skrzydło, bo w tym czasie miał znacznie poważniejszy problem na lewej flance, będącym jedynym w czasie tej bitwy groźnym dla strony polskiej wydarzeniem. Korzystając z osłony silnego wiatru i pyłu Tatarzy Orak mirzy wraz z bejem Widynia, uderzyli na tabory. Wedle słów Koniecpolskiego:

na zadni pułk widyński pasza, wybrawszy kilka tysięcy komunika, z wielką rezolucyją nastąpił, gdzie byli ludzie J.M.P wojewody ruskiego, i pułk pana starosty żydaczewskiego. Lubo był trochę wielką furią swoją wsparł naszych, ale gdy tak z obozowych wałów, jako i polnej reduty wzięto go w bok strzelbą, nasi

15 Stanisław Koniecpolski do Władysława IV, obóz pod Kamieńcem Podolskim 27 X 1633, [w:] Korespondencja..., s. 166-167.

${ }^{16}$ Diariusz..., s. 272.

${ }^{17}$ Kronika Pawła Piaseckiego..., s. 395. 
się też poprawili i insze nastąpiły posiłki, gdzie też i ja sam przypadł. Wsparty mężnie nieprzyjaciel wiele trupa i przednich ludzi na placu zostawił ${ }^{18}$.

Jak zaś opisywał uczestnik walko stronie tureckiej:

Po pięciu godzinach marszu tabor oblężono. W czasie czterogodzinnych zaciętych walk Tatarzy wyparli niewiernych z taboru, a nawet weszli do drugiego, znajdującego się wewnątrz tego i wzięli ponad piętnaście chorągwi ${ }^{19}$.

Zdobycie 15 chorągwi było prawdopodobne, bowiem:

[Z] tyłu, gdziem wspomniał, że alteram frontem dlatego był Pan Hetman z chorągwi szesnastu uczynił i taborki i redutami obwarował, o mały włos i wojsko i ojczyzna nasza nie zginęła, bo nieprzyjaciel z daleka obwiodszy wielką częścią wojska, część jego przytarł potężnie na nich, gdzie, że się niektóre chorągwie ladajako stawiły, wielkie się pomieszanie stało, tak że już w pół wojska naszego aż przed chorągwią samą P. Starosty Kałuskiego Turczyna mężnie się broniącego pojmano. Przypadł Pan Hetman ad tumultum i już też przecie były te chorągwie do przyszły i znowu te chorągwie wspierały tym bardziej confirmatae praesentia ducis, posilone innymi chorągwiami z innych pułków, więc że Pan Wojewoda bracławski następował, ustąpili Turcy z niemałą szkodą swoją, bo i z obozu i z szańców rażono ich z armaty, a nawet i ciurom się ich dostało ${ }^{20}$.

Jedyna groźna dla strony polskiej sytuacja w czasie bitwy została opanowana dzięki wykorzystaniu rezerw hetmana. Straty tureckie miały być znaczne, ale nie pozbawiły armii namiestnika sylistryjskiego zdolności bojowej. Polec miał bej Wizy, zięć, brat i syn Kantymira, zaś Ipsir bej, siostrzeniec Abazy paszy został ranny. Zginęło około 800 żołnierzy tureckich, wielu odniosło obrażenia lub dostało się do niewoli. Sam dowódca turecki, jako prowadzący jeden z ataków, miał stracić konia i zostać niegroźnie postrzelony. Straty polskie nie mogły przekroczyć kilkudziesięciu ludzi, ze względu na przewagę ogniową i niewiele okazji do walki wręcz. Nie zginął ani nie został ranny żaden znany z imienia oficer Koniecpolskiego. Dopiero zapadający zmierzch przerwał starcia i pozwolił wycofać się Turkom²1.

Po niepowodzeniu pod Kamieńcem zaczęło upadać morale wśród żołnierzy osmańskich. Nasiliły się dezercje, szczególnie wśród Mołdawian i Wołochów, których połowa miała uciec jednego dnia spod sztandarów paszy. Następnego dnia przybyli do obozu polskiego posłowie hospodarów z pismem od Abazy

${ }^{18}$ Stanisław Koniecpolski do Władysława IV..., s. 167.

19 Turek Hasan do przebywającego w Konstantynopolu na galerach Ahmeda beja, syna Ibrahima paszy [pod Kamieńcem, 24 października 1633], [w:] Katalog..., s. 285.

${ }^{20}$ Diariusz..., s. 272.

${ }^{21}$ L. Podhorodecki, Wojna..., s. 52. 
paszy oraz informacjami o nastrojach wśród Turków. Po klęsce pod Kamieńcem Abazy ruszył 24 października na Studzienicę, koło której była druga po Chocimiu najdogodniejsza przeprawa przez Dniestr. Jak opisuje to Piasecki:

Bojąc się więc doświadczać ostatecznego losów wojennych wypadku, rozkazał Abazy basza do odwrotu zatrąbić i skwapliwym krokiem w noc późną trzy mile drogi ubieżał, póki się do obozu swojego za Dniestrem miastu Rynczugowi przeciwległego nie dostał. I nie wrócił już więcej; ale po trzydniowym dobywaniu wsi Studzienicy na brzegu Dniestrowym opodal obozu swego leżącej i od samego tylko ludu wiejskiego w strzelbę i prochy niedobrze opatrzonego bronionej, gdy na koniec blisko tysiąca ludzi ze swoich utraciwszy wieś tę pożarem zniszczył, do Dunaju odszedł i wojsko swoje rozpuścił ${ }^{22}$.

Dziwne i najprawdopodobniej błędne było w tym czasie zachowanie Koniecpolskiego. Do Studzienicy nie było daleko, w każdej chwili mógł udzielić pomocy jej mieszkańcom, zwłaszcza, że broniona była tak długo. Zaniechanie pościgu, albo odsieczy dla mieszkańców Studzienicy, ocaliło armię Abazy paszy, która po przekroczeniu Dniestru liczyła z powodu dezercji i strat bojowych zaledwie 13-14 tys. zdemoralizowanych żołnierzy. Mimo przewagi liczebnej można było ją jeszcze nie tylko pokonać, ale i zniszczyć $^{23}$. Nie wydaje się trafne tłumaczenie Piaseckiego (chociaż Koniecpolski miał pewne powody by tak uważać), że zaniechano pościgu z powodu obaw przed sprowokowaniem konfliktu z Imperium Osmańskim, bo Studzienica leżała jeszcze po polskiej stronie granicy. Hetman znał kierunek odwrotu, a jak pokazały dalsze wypadki, sandżakbej sylistryjski i tak doprowadził do formalnego wypowiedzenia wojny ${ }^{24}$. Hetman dopiero 27 października, po otrzymaniu wiadomości o zdobyciu i spaleniu Studzienicy oraz pod wpływem pogłoski, że wróg chce iść na Mohylew ${ }^{25}$ rozpoczął pościg. Pasza rozesłał tymczasem zagony po okolicznych wsiach, ale wkrótce zawrócił i idąc wzdłuż Dniestru wrócił na tereny podległe sułtanowi. Z pewnością duży wpływ na nastroje tureckich żołnierzy miały fałszywe pogłoski, rozpowszechniane przez ludzi Koniecpolskiego, o zbliżaniu się 15000 Kozaków $\mathrm{z}$ frontu moskiewskiego ${ }^{26}$.

Mimo ewidentnego niepowodzenia wyprawy, Abazy pasza przedstawił ją sułtanowi jako zakończoną sukcesem. Wysłał kilka raportów do wysokich dostojników osmańskich, w których przedstawiał swoją wersję wydarzeń.

${ }^{22}$ Kronika Pawła Piaseckiego..., s. 395.

${ }^{24}$ Kronika Pawła Piaseckiego..., s. 395.

${ }^{25}$ O kierunku pościgu na Mohylew por. Stanisław Koniecpolski do Władysława IV..., s. 168; L. Podhorodecki, Wojna..., s. 55.

${ }^{26}$ Stanisław Koniecpolski do Władysława IV..., s. 167. 
Pierwsza relacja była chyba pisana jeszcze w trakcie walk i przedstawiała walki w sposób następujący:

Wielka bitwa, trwająca około czterech godzin, skończyła się zwycięstwem wojsk muzułmańskich i wielką klęską wroga. Padło kilka tysięcy niewiernych, zwycięzcy zdobyli wiele dział i strzelb, a sami utracili tylko 5-10 ludzi i koni. List ten pisze Sulejman efendi podczas szturmu na obóz [zazn. A.B.] ${ }^{27}$.

Zdumiewające, że autor opisuje bitwę jako zwycięską, kiedy ta jeszcze trwała. Chociaż opis prawdopodobnie był sporządzony na bieżąco, przez osobę dzięki stanowisku dobrze obeznaną z realiami starcia, jego wiarygodność, nie jest zbyt duża. Bez wątpienia wpływ na nieprawdziwość danych miał Abazy, pilnujący, by niewygodne fakty nie dotarły do uszu sułtana i tym samym nie ściągnęły gniewu na niefortunnego dowódcę.

Kolejny opis, tego samego autora, powstał w tym samym dniu, ale podaje już mniej fantastyczne liczby:

Po pięciu, a może sześciu godzinach zaciekłej walki w obozie, siły muzułmańskie cofnęły się, by nie narażać się na ogień dział i strzelb z zamku, alei tak odniosły zwycięstwo, ścinając głowy 700-800 niewiernym, biorąc języki i zdobywając 40 sztandarów ${ }^{28}$.

Jednego dnia powstały dwa różne opisy tego samego autora. Być może wpływ na zmniejszenie liczby poległych „giaurów” miała osoba adresata i możliwość zweryfikowania tych danych. Bardziej wstrzemięźliwa relacja, napisana przez Turka Hasana, nie rozstrzyga, kto wygrał starcie, ale jest w niej stwierdzenie, że Tatarzy po 4 godzinach walk wyparli obrońców z jednego z taborów i wzięli 15 sztandarów, po czym wycofali się na noc do obozu $^{29}$. W tych relacjach wysłanych na dwór i do urzędników sułtańskich są zauważalne sprzeczności, ale mimo to sułtan uwierzył awanturniczemu namiestnikowi. By być bardziej wiarygodnym, wziętych do niewoli mieszkańców Studzienicy namiestnik kazał przebrać w polskie stroje i odesłać do Konstantynopola, jako dowód swojego zwycięstwa, zaś jedną z mieszczanek przedstawił na dworze jako córkę hetmana ${ }^{30}$. Po tym „sukcesie” Abazy stał

27 Sulejman efendi do Kenana paszy, [pod Kamieńcem, 23 października 1633], [w:] Kata$\log \ldots$, s. 283.

${ }^{28}$ Ibidem, s. 284. Taką samą relację Sulejman napisał również do swojej żony: Sulejman efendi do swojej żony w Stambule [pod Kamieńcem 23 października 1633], [w:] ibidem, s. 284.

29 Turek Hasan..., s. 285.

30 Sytuacja była tym bardziej groteskowa, że hetman nie miał wtedy córki. Jak dość dowcipnie napisał w liście do biskupa Jakuba Zadzika: „Aleć [...] niesłychaną rzecz oznajmuję, iż ja córki nie mając, będę miał cesarza tureckiego zięcia. Tenże szalbierz [Abazy pasza - przyp. A.B.] czy w Studenicy, czy w Wołoszech dostał prostego narodu dziewki, ale słyszę urody 
się aż do lipca 1634 faworytem sułtańskim, a sam Murad postanowił wypowiedzieć oficjalnie wojnę Rzeczypospolitej.

\section{Zakończenie}

Napięta sytuacja między Imperium osmańskim a państwem polsko-litewskim trwała jeszcze rok, tym bardziej że z powodu trudności skarbowych wysłano poselstwo Aleksandra Trzebińskiego dopiero w grudniu 1633 r., a sam dyplomata nie był już w stanie wypełnić powierzonego mu zadania i zażegnać wojny z Portą ${ }^{31}$. Wydaje się, że po stronie tureckiej wyciągnięto wnioski z nieudanej wojny chocimskiej podczas przygotowań do najazdu na Rzeczpospolitą. 8 kwietnia, o 3 tygodnie wcześniej niż Osman II idący pod Chocim w 1621 r., Murad IV wyruszył do Adrianopola, przeznaczonego na miejsce koncentracji wojsk, chcąc zapewne dotrzeć do polskiej granicy przed jesienią. Szpiedzy Koniecpolskiego donosili o zebraniu przez niego 40000 ludzi, przede wszystkim piechoty i 80 dział pod Adrianopolem, podali też nazwiska dowódców ${ }^{32}$. Inni podawali, że Turków ma być ponad

bardzo pięknej, tę ustroiwszy, wziąwszy hospodarowi gwałtem karetę z sześcią koni, cesarzowi ją za córkę moję posłał. Jeżeli król August Roksolanę za siostrę przyjmował i ja się tej kochanej córki przeć nie będę", [Stanisław Koniecpolski] do Jakuba Zadzika, [XI/XII 1633], [w:] Korespondencja..., s. 192.

${ }_{31}$ Aleksander Trzebiński do Stanisława Koniecpolskiego [Konstantynopol ok. 6 IV 1634], [w:] Korespondencja..., s. 219-229.

32 „Już 8 junii ruszył cesarz z Adrianopola, z wielką potęgą idzie, a sam ma przyjść do Dunaju 28 iunii, tak sobie noclegi porachowali. A skoro przyjdzie do Dunaju Tatarowie mają przechodzić za Dniestr. Raczże WMP wiedzieć, że zapewne nieprzyjaciel ciągnie z wielką potęgą na Koronę Polską. Dnia dzisiejszego przybieżeli stamtąd do cesarza ludzie hospodara dając znać, że już się pogaństwo ruszyło i ciągnie do Polski nieprzeliczonym wojskiem. Dział samych 800 [zapewne błąd w kopii - przyp. A.B.] prowadzą, prócz kilkudziesiąt burzących. Piechoty, tj. semenów najwięcej niż konnego wojska. Abaza wszystkim regimentuje. Murtazy Pasza był w złych terminach, mało go sułtan nie ściął, tylko, że sobie w namiocie pod bajram podpił i ledwo go Abaza uprosił [...] Moskwa krzywoprzysięga i dotąd pobudza Turczyna, aby koniecznie kontynuował wojnę z jednej strony a oni z drugiej. Tatarzyn sam jeden poraniony przybył do Jass, który był w Moskwie z sołtanem i bieży wprost do cesarza każąc się nieść, by też miał w drodze zdechnąć, ale by tylko powiedział cesarzowi tureckiemu, jak wielką szkodę ponieśli Polacy od Moskwy, a dotąd nie mają pokoju, a sam KJM poszedł do Wilna. Tak sam rozgłosił ten pies pogański, nie wiem, jako się przekradł że sam przybył od wojska tatarskiego od JKM, które było z Moskwą [...] Po napisaniu listu mego do WMmmp tegoż dnia przyszedł sam do Jass czausz od cesarza tureckiego do hospodara, gdzie pisze w liście swoim do niego: jeżeli sobie żądasz długo żyć na tym państwie [...] tedy rozkazuję, nim przyjdzie drugi czausz 20000 wojska mieć gotowego [...] Druga, żebyś miał pilne oko na szpiegi polskie i onych łapał i do mnie odsyłał, a co się dzieje dawał mi znać. Nie zawadzi swoich z listem posłać do Hospodara [...] Sroży się pies pogański, mówiąc, że nie da się zwieść jak jego brat Osman podar- 
118000 . Choć były to liczby przesadzone, po zakończeniu mobilizacji i połączeniu z siłami Abazy paszy ocenianymi na 20 000, armia turecka mogła być porównywalna z tą spod Chocimia w $1621 \mathrm{r}^{33}$ Tymczasem 14 czerwca 1634 r. państwo polsko-litewskie zakończyło wojnę z Moskwą. Pokój polanowski sprawił, że wojska Władysława IV mogły zostać skierowane na inny front, tym bardziej że jeszcze przed powrotem Trzebińskiego wiedziano o nastrojach w Konstantynopolu, bowiem ten wysyłał regularnie szyfrowane listy do hetmana ${ }^{34}$. W sumie do walk z Turkami przygotowano 62000 żołnierzy, w tym bezprecedensową liczbę 26000 żołnierzy zaciężnych (13 500 koni i 12500 piechoty), 18700 żołnierzy prywatnych, 16000 Kozaków. Była to jedna z największych armii, jaką zebrano w dziejach Rzeczypospolitej Obojga Narodów. Informacje o zwycięskiej armii polsko-litewskiej gromadzącej się pod Kamieńcem Podolskim, połączone z danymi o faktycznym przebiegu wyprawy Abazy paszy, sprawiły, że uznano kontynuowanie wojny za ryzykowne. Ostatecznie 19 sierpnia 1634 r. ustanowiono pokój między Rzeczpospolitą a Turcją na zasadach zbliżonych do dotychczasowych. 5 sierpnia, jeszcze przed wiadomościami od Szahina agi, sułtan odwołał wyprawę i powrócił do stolicy, zaś 24 sierpnia rozkazał udusić Abazy paszę. Dnia 26 października 1634 r. Murad IV zatwierdził układ pokojowy i w ten sposób zakończono wojnę, zanim się ona naprawdę rozpoczęła ${ }^{35}$.

kami, ale [...] stolice swą w Kamieńcu założy i pójdzie dalej w ziemie aż pod Kraków. 20 julii ma być na Cecorze pewnie i nieomylnie, bo już piąty dzień wyszedł z Adrianopola. Imiona murzów przedniejszych: Sołtan murza, Orak murza, Sziryn murza, Tiutomir murza, Szachmambet Murza, Tanurchaj Murza - siostrzeniec Kantymirów, Santymir murza - syn Kantymirów, Dzialat Murza, młodszy Kantymirów syn, młodszych innych siła. Wojska wszystkiego 40 000", [N.N.] do Stanisława Koniecpolskiego, [Jassy] 14 VI 1634, [w:] Korespondencja..., s. 240-241.

${ }^{33}$ L. Podhorodecki, Wojna..., s. 59.

${ }^{34}$ Korespondencja..., s. 205-206, 209-211, 214-216, 219-229.

${ }^{35}$ Ibidem, s. 71. 


\section{BIBLIOGRAFIA}

\section{Źródła}

Diariusz z obozu spod Kamieńca opisany przez J.M. Pana Mikołaja Hrabię na Ostrorogu, Podstolego Koronnego, Rohatyńskiego, Drohowiskiego, Lisiańskiego, etc. Starostę dnia 27 października 1633 roku, [w:] Pamiętniki o Koniecpolskich. Przyczynek do dziejów polskich XVII wieku, wyd. S. Przyłęcki, Lwów 1842, s. 270-273.

Katalog rękopisów orientalnych ze zbiorów polskich, t. 1, cz. 1: Katalog dokumentów tureckich. Dokumenty do dziejów Polski i krajów ościennych w latach 1455-1672, wyd. Z. Abrahamowicz, red. A. Zajączkowski, Warszawa 1959.

Korespondencja Stanisława Koniecpolskiego hetmana wielkiego koronnego 1632-1636, wyd. A. Biedrzycka, Kraków 2005.

Kronika Pawła Piaseckiego, biskupa przemyślskiego. Polski przekład wedle dawnego rękopismu, poprzedzony studyjum krytycznem nad życiem i pismami autora, wyd. A. Chrząszczewski, Kraków 1870.

Zatargi z Ottomanami z powodu Kozaków i dziennik woyny chocimskiey z roczników Naima Efendi, [w:] Collectanea z dziejopisów tureckich rzeczy do historyi polskiey służacych. $Z$ dodatkiem objaśnień potrzebnych i krytycznych uwag, wyd. J.J. Sękowski, t. 1, Warszawa 1824.

\section{Opracowania}

Barkey K., Bandits and Bureaucrats: The Ottoman Route to State Centralization, Ithaka 1994. Czapliński W., Władysław IV i jego czasy, Wrocław 1974.

Czermak W., Plany wojny tureckiej Władysława IV, Kraków 1895.

Dobrowolska W., Chmielecki Stefan, [w:] Polski Słownik Biograficzny, t. 3: Brożek Jan - Chwalczewski Franciszek, Kraków 1937, s. 318-320.

Górka O., Liczebność Tatarów krymskich i ich wojsk, „Przegląd Historyczno-Wojskowy” 1936, t. 8, nr 2, s. 185-295.

Kroll P., Prywatna wyprawa tureckiego paszy na Rzeczpospolita w 1633 r., http://www.wilanow-palac.pl/prywatna_wyprawa_tureckiego_paszy_na_rzeczpospolita_w_1634_r.html dostęp: 10.07.2017.

Pajewski J., Buńczuk i koncerz, Warszawa 1960.

Pieńkowski M.A., „Jak Osmanowa potęgę żelazem zniósł”. Najazd Abazy paszy i bitwa pod Kamieńcem Podolskim (Paniowcami), https://histmag.org/Jak-Osmanowa-potege-zelazemzniosl-Najazd-Abazy-paszy-i-bitwa-pod-Kamiencem-Podolskim-Paniowcami-8588 dostęp: 10.07.2017.

Podhorodecki L., Hetman Stanisław Koniecpolski, Warszawa 2011.

Podhorodecki L., Wojna polsko-turecka 1633-1634, „Studia i Materiały do Historii Wojskowości" 1978, t. 20, s. 27-72.

Shaw S., Historia Imperium Osmańskiego i Republiki Tureckiej, t. 1, 1280-1808, Warszawa 2012. 
Arkadiusz Bożejewicz

\section{BATTLE OF KAMIENIEC PODOLSKI 22 ${ }^{\text {ND }}$ OCTOBER 1633 - DESCRIPTION ATTEMPT}

$\mathrm{D}$ uring the war of the Polish-Lithuanian Commonwealth against Russia in 1632-1634, at the same time one of the Turkish officials, Sandzakbej of Silistria Mehmed Abazy pasha, invaded the area of Kamieniec Podolski. Both the Turkish and Polish-Lithuanian commanders had similar organizational problems. Due to the war of the Commonwealth with Russia and the Ottoman Empire with Persia, this conflict has been taking place in the shadow of major struggles on distant fronts, making it impossible to use the full potential of struggling states. It was necessary to cooperate with other entities (for Koniecpolski with borderland magnates and Cossacks) for Abazy Mehmed with Ottoman vassals, some Tatar tribes and other governors of Turkish provinces), even communication with the central authority was extremely unstable. Despite this, thanks to better organization, gathering information about the enemy, proper preparation of the area, experience of the Swedish wars of 1626-1629 and his own skills, hetman Koniecpolski was victorious in the battle of Kamieniec Podolski on October 221633.

Keywords: Stanislaw Koniecpolski, Wladislaw Vasa, battle of Kamieniec Podolski 1633, Tartars, Crimean Khanate, Abaza Mahmed pasha, Murat IV, Nogai Horde, Khan Temir, Kantemir, Polish- Ottoman War 1633-1634, Raid of Abaza pasha, Moldavia, Wallahia, Republic of Both Nations, Poland, Lithuania, Smolensk war 1632-1634, early modern Times, military history, Ottoman Empire, Turkey. 